\title{
Socio-economic changes and their implication in the consumption and trade of meat during the La Tène period in Northern France: the cases of the Villeneuve-Saint-Germain and Condé-sur-Suippe (Aisne) oppida
}

\author{
Pierre-Emmanuel PARIS \\ Université Paris 1 Panthéon-Sorbonne, \\ UMR 8215 Trajectoires. De la sédentarisation à l'État, \\ 21 allée de l'Université, \\ F-92023 Nanterre cedex (France) \\ paris.pierre@hotmail.fr
}

Published on 26 June 2015

KEY WORDS Oppidum archaeozoology, consumption, economy, butchery.

MOTS CLÉS Oppidum archéozoologie, consommation économie,
viande, boucherie.
Paris P.-E. 2015. - Socio-economic changes and their implication in the consumption and trade of meat during the La Tène period in Northern France: the cases of the Villeneuve-Saint-Germain and Condé-sur-Suippe (Aisne) oppida. Anthropozoologica 50 (1): 5-20. http://dx.doi.org/10.5252/az2015n1a1

\section{ABSTRACT}

Over the last two centuries B.C., Northern Gaul is confronted with a severe socio-political crisis revealed by a phase of considerable urban development. The re-organization of the territory deeply alters the landscape of Belgic Gaul as the signs of actual Gallic city-states emerge. This rapid and complete transformation of society provokes major economic changes, particularly involving meat resources. New butchering methods appear in certain pre-Roman sites, diet seems to become more standardized and the trade of meat and agricultural primary foods occupies a prominent position in the economy both within and between territories. This archaeozoological study of two large urban entities in the Aisne valley (France), the oppida of Villeneuve-Saint-Germain and Condé-sur-Suippe, dating from La Tène D1/D2, reveals differences in meat management and preparation, as well as diet.

\section{RÉSUMÉ}

Les changements socio-économiques et leur implication sur la consommation et le commerce de la viande à La Tène dans le nord de la France : le cas des oppida de Villeneuve-Saint-Germain et de Condé-surSuippe (Aisne).

Durant les deux derniers siècles avant notre ère, la Gaule septentrionale est confrontée à de sévères crises socio-politiques révélées par une phase de très fort développement urbain. La réorganisation du territoire marque en profondeur les paysages de la Gaule belgique alors qu'émergent les véritables cités-états gauloises. Cette rapide et complète transformation de la société provoque des changements économiques majeurs, notamment en ce qui concerne les ressources carnées. De nouvelles techniques de boucherie apparaissent sur certains sites pré-romains, l'alimentation devient plus standardisée et le commerce de la viande et des productions agricoles occupe une position prééminente dans l'économie, à la fois au sein des territoires et entre eux. Cette étude archéozoologique de deux grandes entités urbaines de la Vallée de l'Aisne (France), les oppida de Villeneuve-Saint-Germain et Condé-sur-Suippe, datés de La Tène D1/D2, révèle des différences dans la gestion et la préparation des viandes, tout comme dans l'alimentation. 


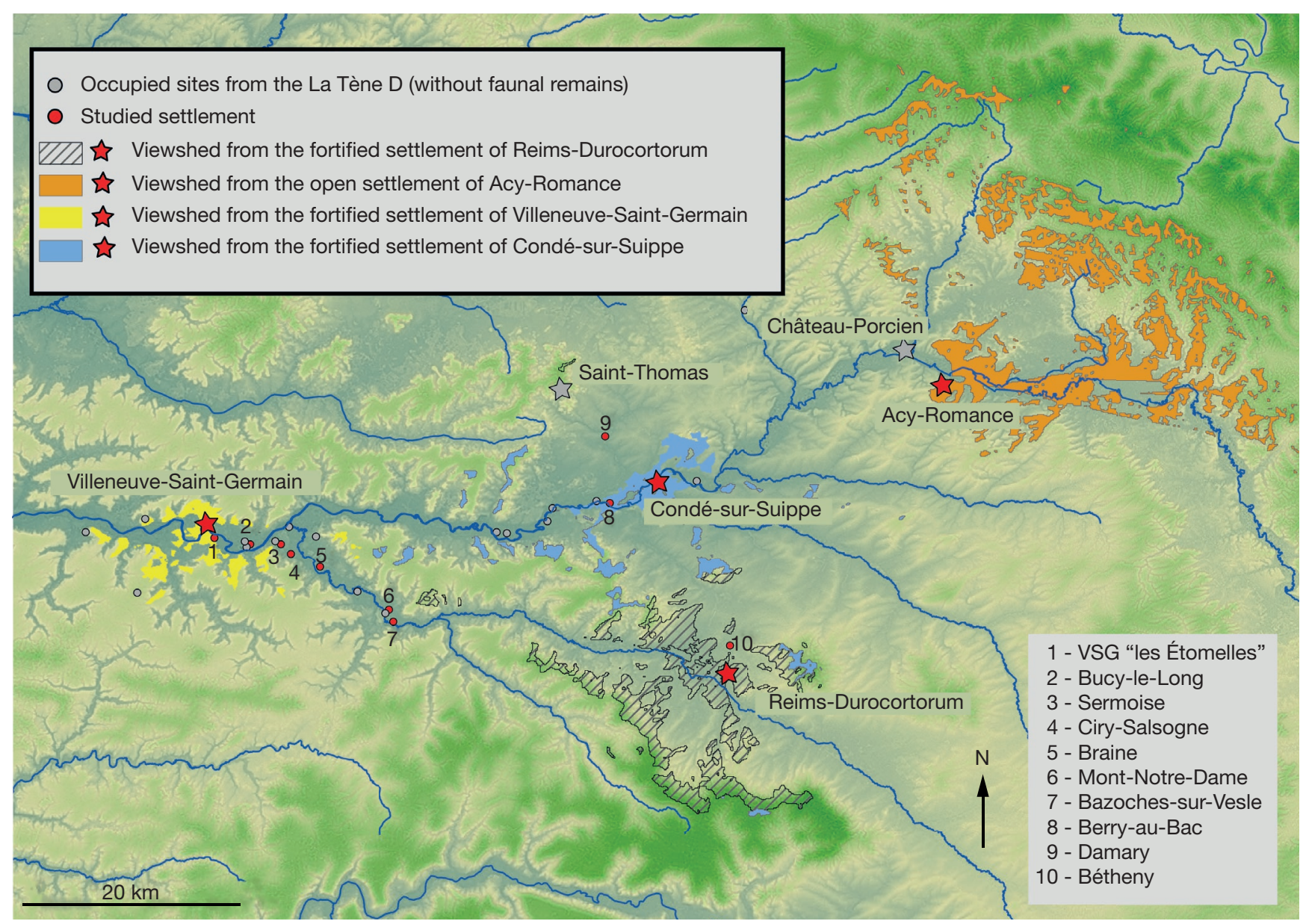

FIG.1. - Distribution of some late Iron Age sites in the study region.

\section{INTRODUCTION}

In order to fully understand the management and consumption of animal resources as they relate to the populations at the very end of the Iron Age, it is important first to note the dietary trends that were gradually established. Since the first evidence of domestication in the Neolithic period, humans have continued - in line with their needs and the environment in which they found themselves - to adapt their diet in order to establish a strategy favourable to social development. In temperate Europe, this resulted in a pronounced orientation of herds from the Late Bronze Age onwards, with populations primarily exploiting the classic domestic "triad" consisting of cattle, pigs and caprinae and consuming only occasionally the results of increasingly rare hunting activities. This domestic triad constitutes the foundation of the animal resources and is supplemented by the consumption on a more or less regular basis, depending on context, of horse and dog meat. During those last five centuries B.C., a variety of economic, political and environmental factors led to a major upheaval in the social equilibrium of the Gallic peoples (Malrain et al. 2002), who were faced with important societal choices, some of which directly related to dietary strategies, significantly modifying the composition of herds and, by extension, the consumption of meat.
We choose here to focus on sampled areas which are representative of that characteristic phase of specialisation of Gallic craftsmen, directly linked to the emergence of oppida. At Condé-sur-Suippe, a blacksmith's workshop has been selected, whereas at Villeneuve-Saint-Germain, we have concentrated on a furriery and butchery quarter, located near the southern ditch. Obviously, the reflections and conclusions reached here are partly guided by the results of previous archaeozoological analyses on other sectors (Auxiette 1996) and the wider studies of the two archaeological sites, which exceed more than 70000 bone remains and are still ongoing (Paris 2015).

\section{DEVELOPMENT OF DIETARY REGIMES IN THE AISNE VALLEY}

As a result of the studies carried out by P. Méniel (1984) and the complementary examination provided by G. Auxiette (1996), the region of the Paris Basin - and more specifically that of the Aisne valley (Fig. 1) - constitutes a solid analytical basis and enables a particularly interesting diachronic reading of the development of dietary regimes. In her article entitled « La faune des établissements ruraux du Bronze final au Hallstatt final/La Tène ancienne dans la vallée de l'Aisne», 


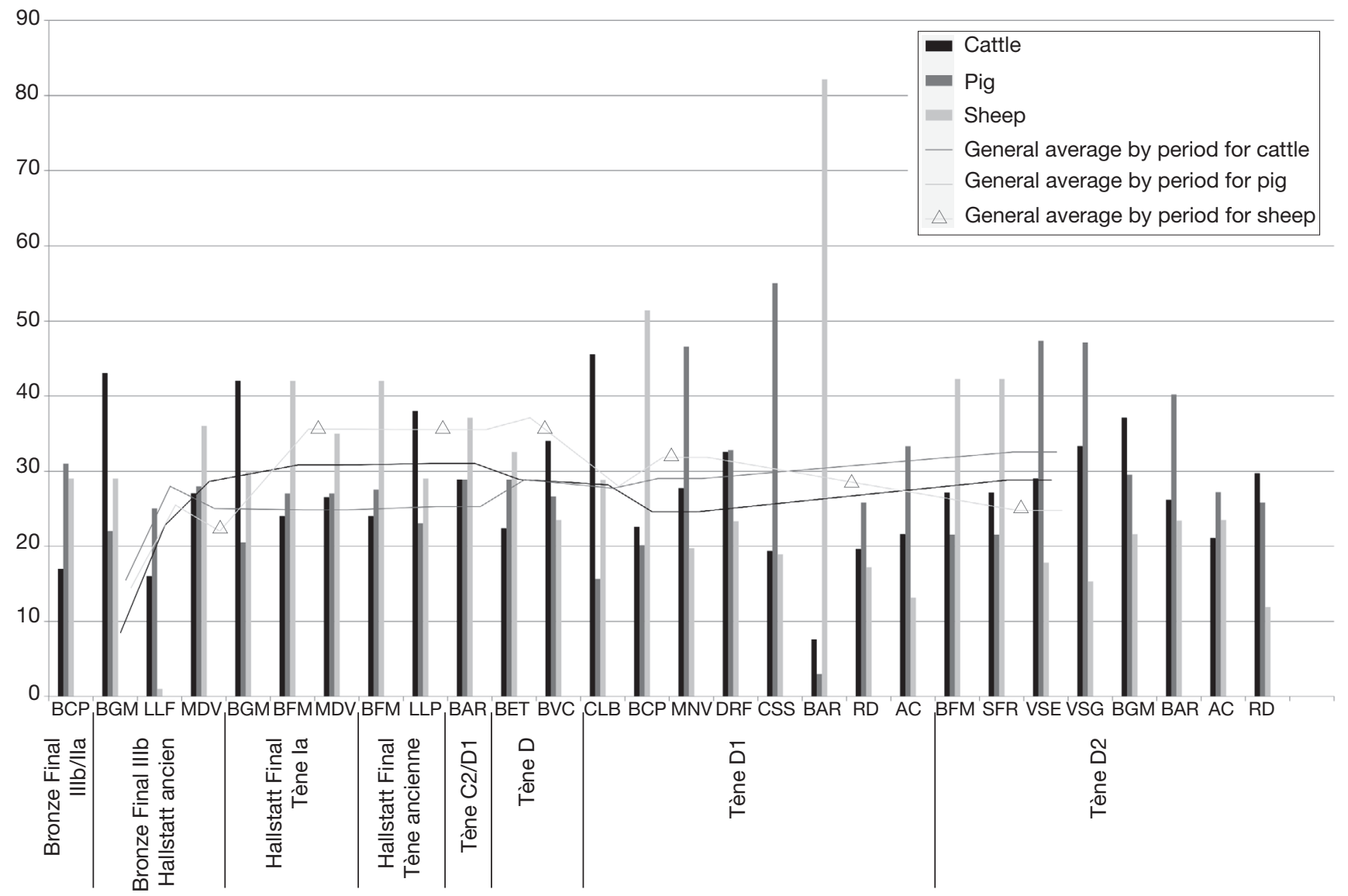

FIG. 2. - Development of herd composition during the Iron Age. BCP, Berry-au-Bac "le Chemin de la Pêcherie"; BGM, Bucy-le-Long "le Grand Marais"; LLF, Limé "les Fussis"; MDV = Menneville "Derrière le Village "; BFM, Bucy-le-Long "le Fond du Petit Marais"; LLP, Limé "La Prairie"; BAR, Baranton; BET, Bétheny "les Equiernolles"; BVC, Bazoches-sur-Vesles "les Chantraînes"; CLB, Ciry-Salsogne "le Bruy"; MNV, Mont-Notre-Dame "Vaudigny”; DRF, Damary "le Ruisseauds Fayau"; CSS, Condé-sur-Suippe; RD, Reims-Durocortorum; AC, Acy-Romance; SFR, Sermoise "les Fausses Rues"; VSE, Villeneuve-Saint-Germain "les Etomelles"; VSG, Villeneuve-Saint-Germain.

G. Auxiette (1997) has already to a large extent initiated this train of thought, particularly through the examination of the representation of the domestic triad and the remains of dogs and horses within archaeological sites whose occupations succeed each other from Hallstatt D until La Tène A (from 625 to 400 B.C.). Through the study of three sites - those of Menneville, Limé and Bucy-le-Long - she has thus reconstructed a portion of the dietary changes carried out among the Gallic populations of the region over more than two centuries. The conclusions drawn are as follows: "Livestock farming in the late Hallstatt/early La Tène is based on a mixed pig/cattle/ caprinae stock; caprinae dominate in terms of MNI for all sites. We observe the "reduction" in the raising of pigs compared to the previous and following periods" (Auxiette 1997: 55). On the basis of the same work implemented by Auxiette to initiate this examination, it appeared to me that the integration of new data recently collected for the two fortified settlements of Villeneuve-Saint-Germain and Condé-sur-Suippe and some rural settlements of the same period was necessary in order to obtain a deeper chronological understanding. An obvious hiatus, probably not due to an archaeological bias resulting from a lack of excavation or defective date of the sites, took place in La Tène Moyenne. In fact this area had a lower frequency of large sites during the $4^{\text {th }}$ and $3^{\text {rd }}$ centuries B.C., which we still cannot easily explain. Despite this hiatus which disrupted - perhaps even diminished - the possible interpretations open to us, it is nevertheless interesting to observe a change, very clearly marked on the graphic below (Fig. 2), in the strategic choices for the management and consumption of animal resources. The general average, calculated for each period, shows that pigs clearly took a predominant place in the composition of the herds during the beginning of La Tène $\mathrm{D}$, at the expense of caprinae. The occasional but significant levels of bovinae observed on some rural settlements and in Villeneuve-Saint-Germain also indicate that the exploitation of this animal increased over time, at least from La Tène D1 onwards (150 B.C.). The frequency of the remains of dogs and horses gradually stabilises and tends towards equilibrium on the site of Condé-sur-Suippe, before undergoing a clear inversion of proportions on the site of Villeneuve-Saint-Germain, where the remains of dogs are much more common than those of horses.

This regional focus - enlarged in comparison to that initially suggested by G. Auxiette - thus enables us to perceive genuine 
mutations in the dietary strategies adopted. We are thus able to question the causes and consequences - both economic and technical - of such societal upheavals which took place between the $3^{\text {rd }}$ and $1^{\text {st }}$ centuries B.C. The modification of dietary regimes seems to indicate a desire by the Gallic people to adapt to a new economic situation, principally dictated by a variety of external factors which applied pressure to these populations and which it is useful to recall here.

\section{SOCIO-POLITICAL AND ECONOMIC CONTEXT}

The Celtic migrations of the $5^{\text {th }}$ century B.C., which originated in a strong demographic movement, a major climatic deterioration (around 430 B.C.) and a particular attraction for the most highly developed Mediterranean regions (Brun \& Ruby 2008: 112) merely delayed the pressures that came to bear, two centuries later, on material and food resources. In response to these pressures, several phenomena gradually came into effect in protohistoric societies; phenomena that archaeologists can measure at least partially.

During the late Iron Age, we observe an intensification of agriculture on archaeological sites (Gransar 2000). From this date onwards, the agricultural system "based on single species and cereal farming [...] produces higher yields" (Matterne 2002: 182). This over-production can be compared directly on the one hand with the change in herd composition undertaken by the peoples of Gallia Belgica. Livestock farming "of large animals, on a large scale" (Auxiette 1996: 84) necessitated increased forage, but at the same time also led to the production of larger quantities of manure, which in turn favoured fertilization and thus agricultural production. On the other hand, this agricultural intensification was in part due to "the progress achieved in the field of equipment and techniques" (Matterne 2002: 182). This is a reference to the significant use of iron in the production of a variety of tools - particularly for agricultural purposes - which was also to play a major role in the possibilities available to the population for more efficiently achieving subsistence.

As we will see, the data accumulated in the fields of carpology, metallurgy and zooarchaeology intersect and constitute indicators of profound economic upheavals which in turn form part of a very specific social and political context.

Commercial and political networks also continued to develop in the late Iron Age. The landscapes of the Gallic peoples were shaped in line with these socio-political transformations, with the appearance from the $3^{\text {rd }}$ century B.C. of large nondefensive settlements which multiplied over the first half of the $2^{\text {nd }}$ century and tended to decline in the second half of the $2^{\text {nd }}$ century B.C. in favour of large fortified settlements. These settlements held much greater populations than the previous open habitations. For example, the population of the settlement of Villeneuve-Saint-Germain, the capital of the Suessione, is estimated to have been 4000 inhabitants, "to restrict ourselves [...] to a conservative estimate" (Brun et al. 2000: 85). The same was true for the settlement of Condé-sur-Suippe, where the estimated figure is also around 5000 inhabitants (Brun \&
Ruby 2008: 135). The various circumscribed territories that divided the Gauls indicate a strong desire for demarcation among all of these peoples. This profound reorganization of protohistoric societies necessarily involved new constraints, both economic - as we have seen - technical and human, in order to meet the challenge of supplying the nutritional requirements of a population concentrated into an area that, although large, was nonetheless restricted. In terms of techniques, whether in the field of agriculture, butchery activity or in the working of iron or bone, increasingly marked craft specialization can be observed, leading us to query how these settlements and their social hierarchies functioned. How were the activities arranged in these urban spaces, and how was the control of production and redistribution organised? From a political point of view, how was trade organised within a territory, but also between separate communities?

Finally, the change of period that took place with the gradual Romanization of the whole of Gaul was an important element that we must not neglect, although this was for a long time over-estimated. The Mediterranean world opening its doors to Celtic Gaul undoubtedly had an influence on some Gallic peoples, and the works of Julius Caesar provide us with good indications of fraternal alliances - alliances which were probably anchored in a more distant past - constructed, for example, with the Aedui or the Arverni. However, the mutation undergone by Gallic societies was a slow process that started in the $5^{\text {th }}$ century B.C. and whose consequences, visible late in the latter centuries of the Iron Age, cannot be attributed to a rapid Roman acculturation, often considered incorrectly as a civilising influence.

We are not attempting here to provide answers to these problems, which have kept a large number of authors busy for several decades. However, it is important to take into account the dietary modifications arising from these social mutations.

If we restrict ourselves to the animal resources, we must question the management of the herds employed in order to guarantee the subsistence of these grouped populations. This means examining all of the means employed to ensure the existence of the overall chaine opératoire leading to the consumption of the animal, i.e. breeding, slaughter, butchery, distribution (where present) and consumption. We have previously observed that there is a genuine dichotomy between the composition and management of herds in the La Tène A and those of the La Tène D. We will attempt to identify these strategic changes through the analysis of two oppida - those of Villeneuve-Saint-Germain and Condé-sur-Suippe - and we will then be able to examine the trade and political implications they may have caused.

The partial zooarchaeological reading of this phenomenon is thus based in part on the spatial analysis of these settlements and in this way questions the role played by the animal resources in the economic life of these populations. It appears that new, complex forms of urbanization were present from La Tène $\mathrm{C} / \mathrm{D}$, the functioning of which is as yet still unknown. This is the case with the settlement of Villeneuve-Saint-Germain, where the entirely covered "cruciform" ditches run for almost $1.8 \mathrm{~km}$ (Rubn \& Auxiette 2010: 66). Their function seems 


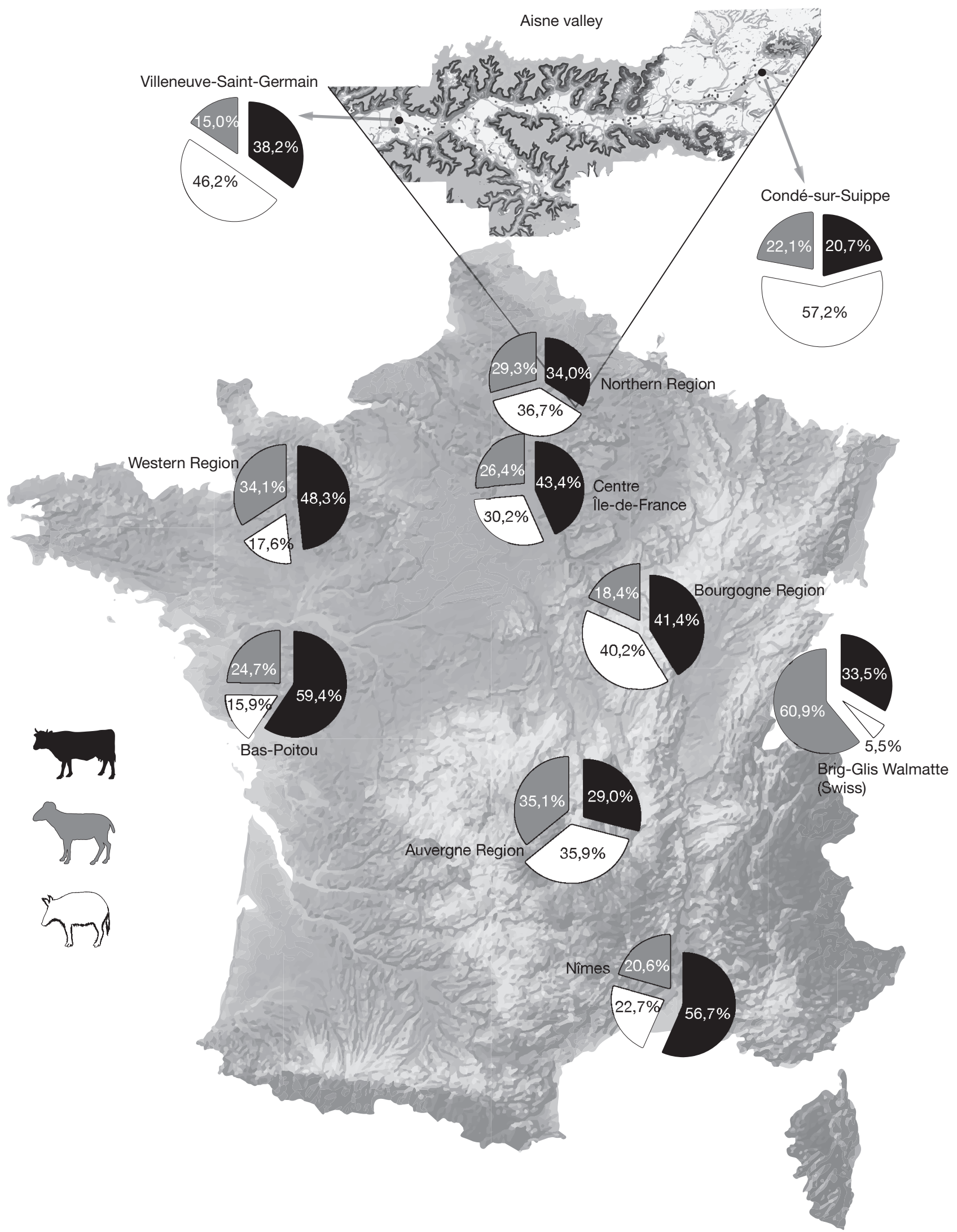

FIG. 3. - General overview of the domestic triad in various Gallic regions. 
at least in part linked to intensive exploitation of animal resources, as we will see later. The site of Condé-sur-Suippe, where the urban context is also particularly well preserved, also offers a concrete illustration of differential management of bone remains, with the use and/or disposal of these varying according to the activity with which they are associated.

\section{PRESENTATION OF THE SITES}

The analysis presented here is based on the partial faunal study, essentially coming from detrital archaeological features, of two settlements located in the heart of the Aisne valley: the first, Villeneuve-Saint-Germain - capital of the Suessione people - is situated approximately $50 \mathrm{~km}$ (50 000 meters) from the second, Condé-sur-Suippe, the stronghold of the Remi people (Fig. 1).

These two archaeological sites, the excavation of which began in the 1970s and is still continuing, extend over more than one hundred hectares (around 100 hectares for the site of Villeneuve-Saint-Germain and a little more than 130 hectares for Condé-sur-Suippe) of which 3 have been subjected to archaeological excavation. The excavation of the site of Villeneuve-Saint-Germain is part of the project "Mission Archéologique de Systématisation Synthétique de l'Information sur Villeneuve-Saint-Germain (Alles nicht verloren)" which has been carried out since 2007 by P. Ruby and G. Auxiette, while the site of Condé-sur-Suippe is still the subject of regular preventive excavations as the industrial facilities located there continue to be developed. The settlement of Condé-sur-Suippe was occupied in the La Tène D1, or between 150 and 90 B.C. (Pion 1998: 88). The site of Villeneuve-Saint-Germain was occupied during the La Tène D2a, between 90 and 50 B.C.

The 1987 excavations carried out by P. Pion (1990) on the settlement of Condé-sur-Suippe have been the subject of a spatial analysis (Pion et al. 1997) together with a complete metallurgical study carried out by $\mathrm{S}$. Bauvais for his master's thesis. The latter was thus able to reveal the whole of a complex ironworking chaîne opératoire, from "cleansing to finishing or assembly of the metal with other materials" (Bauvais 2000: 122), and for which each of the stages of production takes place within very distinct sectors. The choice for our study has therefore fallen more specifically on a workshop for the creation of iron objects, the study of which was begun by G. Auxiette (1994: 74-79). Completing the faunal analysis will enable the provision of an exhaustive and coherent study of the whole of a sector. In total, the analysis is based on the study of 3674 bone remains (cf. Appendix) : G. Auxiette (1994) studied 2820 bone remains, for a ratio of determined remains of $47.2 \%$. The complement of this first study is thus based on the examination of 854 bones, of which $61 \%$ could be determined.

A large number of archaeological excavations have taken place on the site of Villeneuve-Saint-Germain since the first field data gathered by Octave Vauvillé in 1892. The "enlightened amateur" J. Debord and CNRS URA 12 excavated 3 hectares over almost a decade. The recent recommencement of archaeological research on the site has enabled a systematic critique of the models previously employed, particularly those relating to the "cruciform" ditches, which were long interpreted as large-scale market stalls (Debord et al. 1988). In the context of this study, two faunal assemblages have been analysed: one deals with the living zone explored in 1974 by J. Debord, the second focuses on the 2010 excavation carried out on the southern ditch. These two sectors have produced 3111 bones for a ratio of determined remains of more than $83 \%$ (cf. Appendix). The original study carried out here on the living zone has produced 729 bone remains (71\% determined remains) compared to 2385 for the sector of the southern ditch (more than $87 \%$ of remains determined).

\section{HERD MANAGEMENT MODELS OBSERVED IN LA TĖNE D}

As previously mentioned, the meat diet of the Gallic populations was relatively standardised for several centuries. Numerous studies published in the last decade - dealing with this period and covering the whole Gallic territory - tend to emphasize the uniform nature of herd management models, based essentially on husbandry of the domestic triad, despite some regional variations (for example in the Swiss or the southern regions, Fig. 3). The majority of these studies are the result of thesis work (Sidi Maamar 2001; Cambou 2009; Germinet 2009; Foucras 2010; Salin 2010; Baudry 2012; Renaud 2012)

The analysis of the site of Villeneuve-Saint-Germain offers us useful information in this context regarding the management models employed.

Bone remains from the domestic triad dominate in all features; however, in the fill of the southern ditch (feature A732), we note that cattle are particularly prevalent, representing 50\% of the bone remains (while they normally represent between 15 and 30\%). Other than the ditch itself, the remains of pigs are more significant within the assemblages.

Suidae are subject to regular slaughter from the first year of life, and the sex ratio shows a frequency of around one sow to three boars: this demonstrates a classic management model for the animal, with intermittent slaughter of young individuals within the habitation - particularly in feature F04 of the living zone at Villeneuve-Saint-Germain, where two immature individuals have been identified (Fig. 4) - probably in order to regulate births and to retain only few males for reproduction and the majority of boars for consumption.

Caprinae remains are regularly in second place within these sectors, with the exception of the sector of the southern ditch at Villeneuve-Saint-Germain. The management of these herds seems to be different to that of the pig. During the study of the living zone at Villeneuve-Saint-Germain, we observed a specific spatial distribution of goats, represented by three tibias, within three separate features: F12, F04 and F01, which also correspond to three different house units. This observation, however tenuous in our case, confirms the more detailed analysis carried out on the living zone by G. Auxiette (Auxiette 


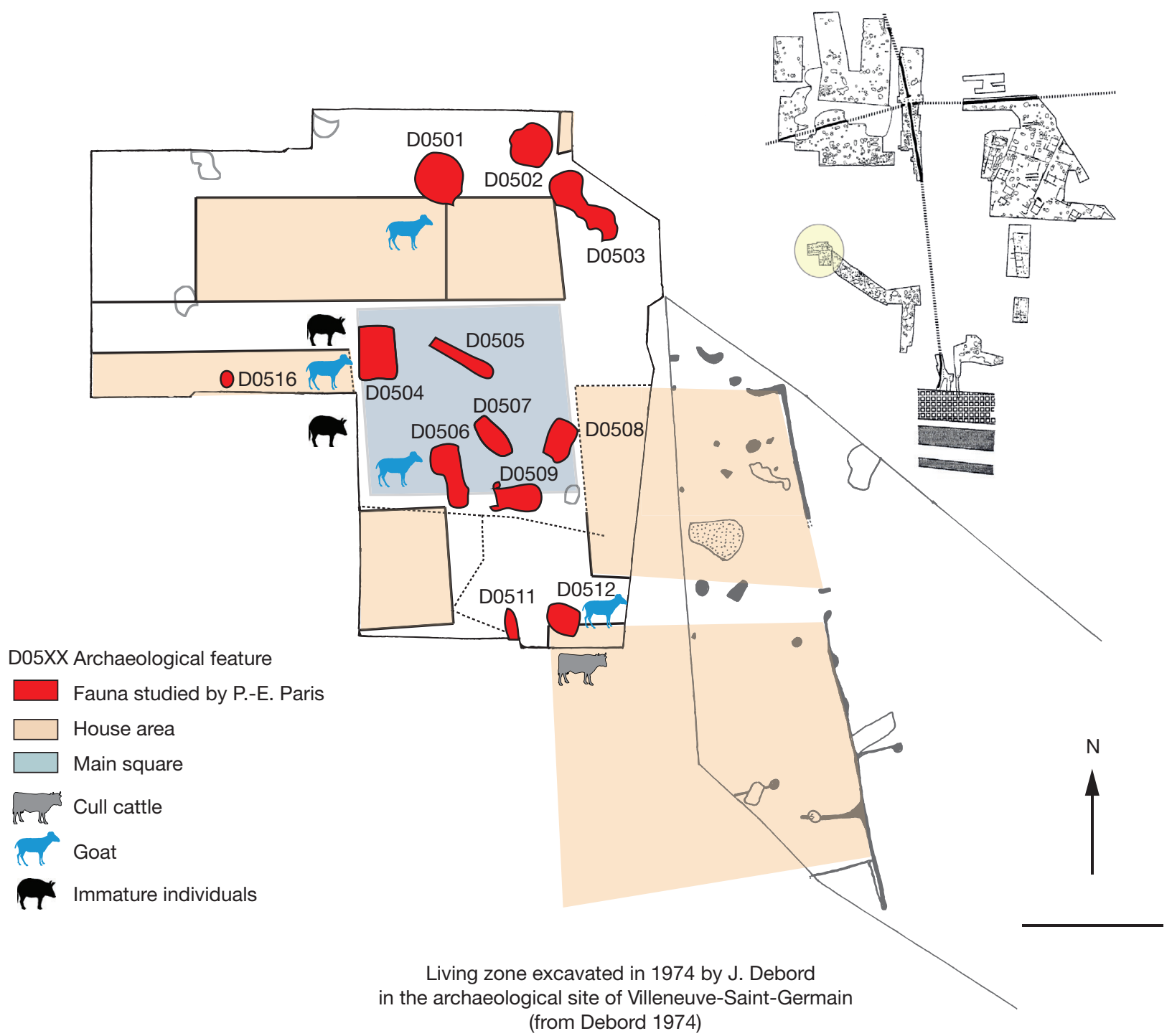

FIG. 4. - Plan of the living zone on the site of Villeneuve-Saint-Germain. Scale bar: $5 \mathrm{~m}$.

1996: 49, 50). Thus all the evidence suggests that this animal was the subject of management on a smaller scale - that of the house unit: it was slaughtered in situ, which suggests that each house unit possessed a small herd whose management was carried out by each household. The frequency of goats in this area is also significant because we observe an underrepresentation of the females who guarantee the reproduction of the herd and provide important secondary materials (milk, wool etc.). They are slaughtered later than sheep, which are primarily consumed once they have achieved mature weight at around two years. The uncastrated males (the rams) are generally difficult to identify. The presence of rams within an assemblage can be detected by means of metric analyses, most often carried out on the metapodes. It was not possible to carry out such an analysis for the current study due to the low number of remains that could easily be measured They are generally rarely present on the site of Villeneuve-SaintGermain (Auxiette 1996: 49, 50), as they were only conserved in order to ensure the reproduction of the herd.
The management of bovinae is also worthy of note, particularly at Villeneuve-Saint-Germain. Generally, the animal is regularly slaughtered between two and three years of age at its optimum mature weight. It is primarily the females which are consumed and which also have the advantage of producing milk, while the males are retained for various draught tasks and to guarantee the reproduction of the species. Bovidae are undoubtedly much more restrictive animals in terms of their breeding, if only due to the size of an individual ${ }^{1}$ and the dietary requirements of a herd. In the habitation sector at Villeneuve-Saint-Germain, a "retired" animal - whose very great age can be estimated due to the extreme wear of one of the teeth found in feature F12 - has been identified. In addition, this feature also contained characteristic waste from

1. On this subject, we should recall that Gallic cattle were generally very different from current standards, with a height at the withers of around $115 \mathrm{~cm}$ (for the site of Villeneuve-Saint-Germain) compared to around $145 \mathrm{~cm}$ for a current cow. cf. the following Internet site for more details (in French): http:// artic.ac-besancon.fr/ecole_primaire_aillevillers/tout $\% 20$ sur $\% 20$ vaches.htm 
animal butchery, with an over-representation of lower leg elements. The hypothesis of an in situ management of "retired" individuals is plausible if we take into account in parallel the systematic slaughter of bovidae in a nearby sector in the "cruciform" trenches. Other than its fill, the southern ditch indicates more large-scale butchery activities than in the living zone. While intensive butchery activity - to which we will return later - is concentrated in this sector, it is not illogical to imagine that the management of older individuals might have taken place on a smaller scale within the living zone due to the different status of the animals thus slaughtered. In addition, across the whole sector, a single bovid skull has been identified; discovered in feature F01, this may also be an indicator as to the management of the species in this living zone. It seems that few individuals were slaughtered in situ, and we are perhaps here observing collective management of slaughter and butchery between one or two house units sharing between one or more house compounds the results of joint exploitation.

It is also important to emphasize that the butchery of pig carcasses was also the rule in the immediate surroundings of the southern ditch, although on a smaller scale than that of the bovidae. We observe a very clear reduction in the frequency of caprinae remains in the sector of the southern ditch, which relegates this species to the level of minority species such as dogs, horses and birds. It appears that there were thus two scales of exploitation: one applied to the house unit, for which the caprinae seem to have been the sole species entirely managed at household level, and the other on the scale of the site, with butchery and redistribution of cattle and pig carcasses carried out in an area close to the ditches (which does not exclude partial management of "retired" individuals or occasional slaughter of pigs within the house unit).

As regards to the "minority" species (dogs, horses and all wild species), it is interesting to observe the differences that existed between the two sites in the use of these species. At Condé-sur-Suippe, the consumption of wild species was greater than at Villeneuve-Saint-Germain. These were principally the results of intermittent hunting activity: wild boar, red deer and cyprinids representing only a very small share of the diet. We also note that on both sites the presence of poultry was very low. The exploitation of poultry species would only be promoted at a later date through Roman acculturation, in the same manner that hippophagy would be gradually proscribed. However, at Condé-sur-Suippe as at VilleneuveSaint-Germain, the consumption of horse meat is attested in different proportions: the Remi seem to have been more inclined to hippophagy in La Tène D1. This is undoubtedly a characteristic cultural distinction between the two populations.

Finally, the status of dogs is ambivalent. Due to the practical advantages of breeding dogs, they were the subject of intermittent consumption on the two sites, but the dog was also a completely separate domestic animal feeding on waste, as is indicated by the recurring bite marks observed on the bones. The breeding of dogs entails several advantages: it produces large numbers of offspring rapidly and the management of this reproduction is made simple, partly due to the capacity of the species to find its own food (by eliminating part of the household waste) and partly due to its sociability, which means that it is not necessary to check on the animal on a regular basis (unlike the other domestic species). The exploitation of dogs also takes on a craft dimension at Villeneuve-Saint-Germain, with the production of dog skins revealed by omnipresent skull and metapode fragments (some of which bear large-scale cutting marks on the proximal part of the joint) within the test pits of the southern ditch, but also in the peripheral ditches. Already highlighted by J. H. Yvinec (1987: 89), and by G. Auxiette (1996: 47), who was able to identify the same fur production activity relating to other species such as fox, badger or beaver, this practice was once again concentrated in the area of the "cruciform" ditches, with dog remains being almost absent in the living zone.

We are thus dealing at Villeneuve-Saint-Germain with the rational management of herds in several forms: firstly, regardless of species - whether bovidae, caprinae or suidae - we observe a regular control of births perceptible as a selection of animals from an early age (the sex ratios being regularly of the order of one female to three or four males), together with managed slaughter via an almost systematic selection in which male individuals (cattle, sheep and pigs) are slaughtered at mature weight.

These controls, taken as a whole, tended to preserve the sustainability of the herd while simultaneously maintaining an essential balance between meat animals and animals intended to ensure the reproduction of the herd. The controls also aimed to optimise production of animal food resources through precise management of slaughter ages (always around the second year of life for pigs and cattle), implying long-term organization.

Lastly, we found evidence on the site of Villeneuve-SaintGermain that suggests the "sharing" of cattle carcasses between different house units, a hypothesis already proposed by G. Auxiette (1996: 50) on the basis of work carried out on another living zone. This notion of "community sharing" is important as it may also have led to the collectivization of herds - at least regarding cattle - between several human groups. On this subject, recent master's thesis work carried out by C. Filet seems to show that there are no systematic spatial divisions relating to craft activities within the majority of La Tène C/D settlements. This may indicate a division of quarters by family lines or clans which would thus have each contained their own craftworkers: "each family, each habitation unit is an independent production cell” (Filet 2012: 117).

\section{TWO OPPIDA, TWO EXPLOITATIONS OF BONE REMAINS}

Other than the questions of animal management and consumption, the analysis of the two sites of the Remi and Suessione peoples also enables us to comprehend two different aspects of the exploitation of animal resources: one contributes to a better understanding of the thinking behind the differential exploitation of bone remains within the settlement, while the other indicates an initial form of meat production on 


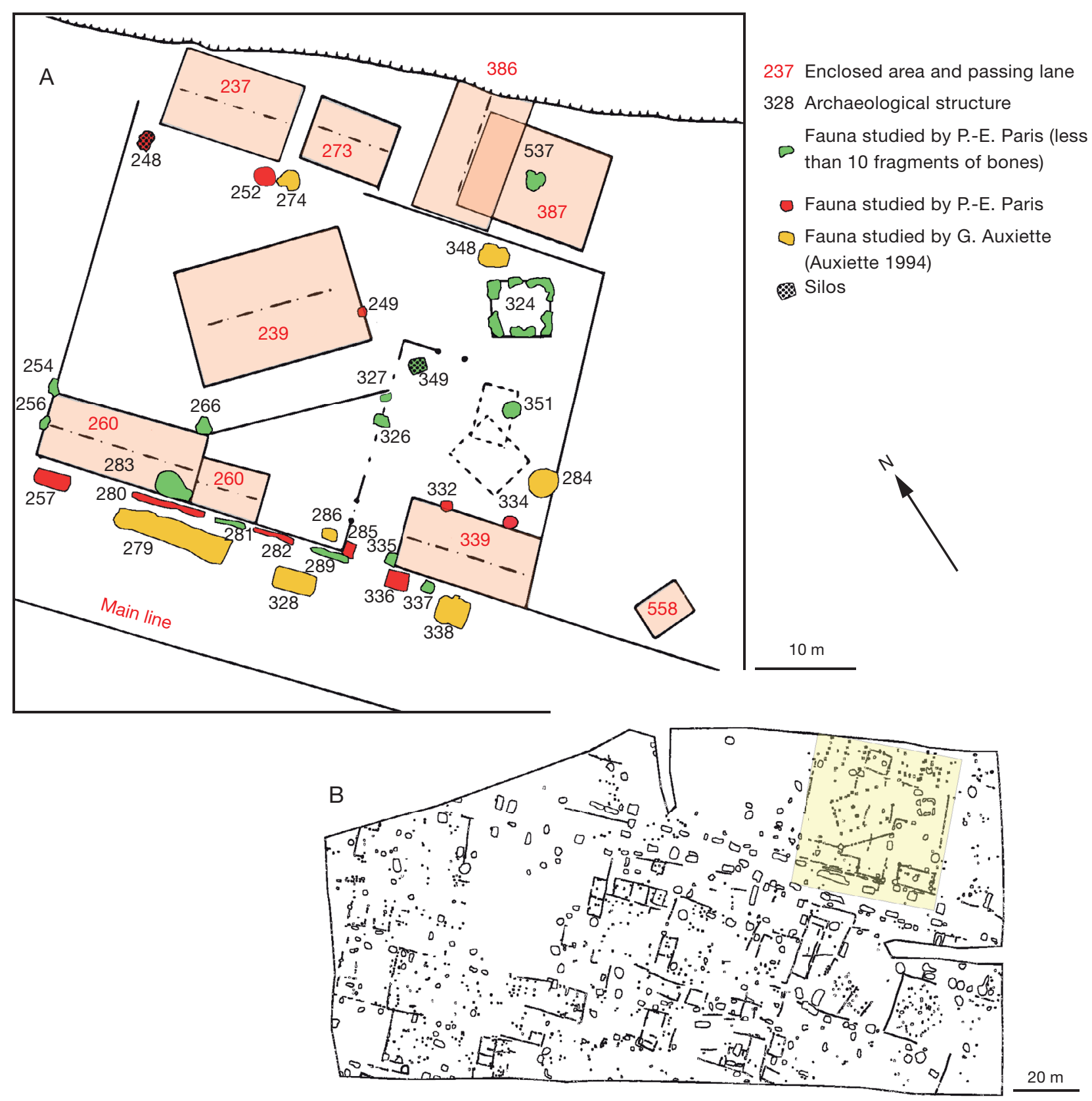

FIG. 5. - A, Plan of one of the forge workshops on the site of Condé-sur-Suippe; B, General plan of the sites of Condé-sur-Suippe "la Sucrerie” (P. Pion 1987).

the scale of a region, or even of a larger territory (that of the Roman "civitates").

The analysis of bone remains from the forge workshop at Condé-sur-Suippe (Fig. 5) has revealed differences between the bone remains from within the workshop enclosure and from the large rectilinear pits alongside one of the main streets of the settlement.

The state of fragmentation of the bone remains is one of the first important aspects to emphasize: inside the enclosure, the bones were regularly and methodically crushed. On average, the weight of a bone fragment within the enclosure is less than 4 grams, compared to more than 8 grams on the main street. In addition, marks linked to consumption or prepa- ration of pieces of meat are rare within the enclosure, while the large rectilinear pits contained a sometimes significant number - for example feature 257, which produced a large number of burnt bones.

G. Auxiette has also made a clear distinction between the two types of pit. She writes: "the first [the pits within the enclosure] produced material that reflect consumption waste. The second [located along the main street] are more indicative of random collection" (Auxiette 1994: 80). The complement to this first analysis makes the situation a little clearer. The fragmentation of the bones is greater within the enclosure, and while G. Auxiette considers this to indicate exploitation of marrow (Auxiette 1994: 79), the extreme fragmentation may correspond to other 


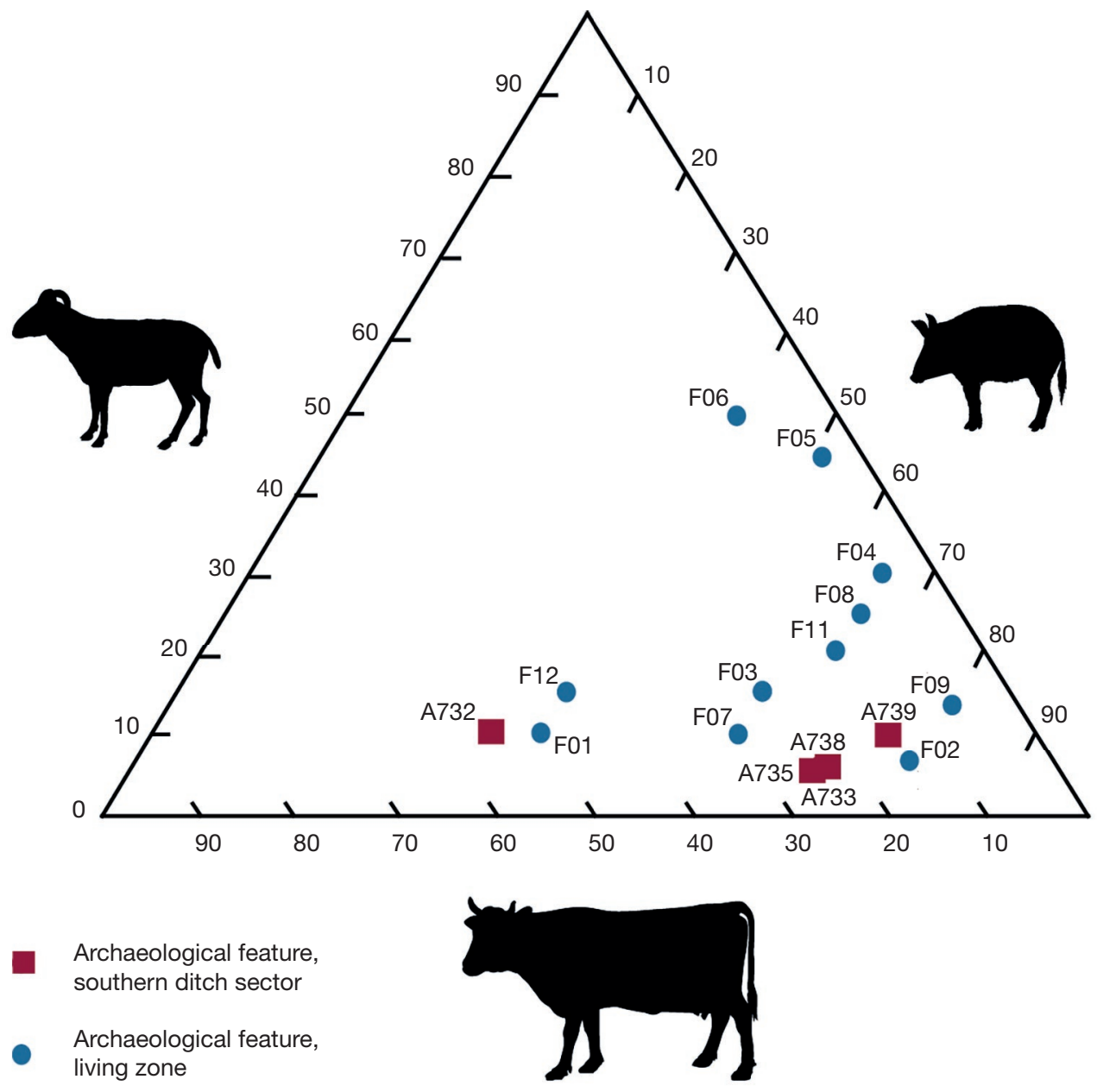

FIG. 6. - Triangle plot presenting variations in the frequency of the three main species between the different archaeological features on the site of VilleneuveSaint-Germain.

types of use, such as the production of fat or "bone glue", for example. This type of use could then be related to the main activity taking place in the enclosure. S. Bauvais, in his study of the metallurgical chaines opératoires, has revealed a phase of the "assemblage of metal with other materials (wood, bronze etc.)" (Bauvais 2000: 122) and confirms his observation, from La Tène C, of metal cementation ${ }^{2}$ techniques - mastered by the Gallic populations - for which bone is an essential agent : (Bauvais pers. comm.). This hypothesis must be verified by a study of all forge workshops on the site.

Concerning the "random collection" of more solid skeletal elements in the pits along the main circulatory axis, one cannot rule out the possibility that taphonomic phenomena may have disturbed our reading of the faunal spectra, as soil acidity levels at Condé-sur-Suippe are high. Nevertheless, in this sector of the site, erosion and vermicules have in no way

2. Cementation is a thermochemical treatment in which carbon is allowed to superficially penetrate a metal with an insufficient carbon percentage, in order to transform the surface into a sufficiently carburised steel to enable it to be hardened. This process can be carried out by plunging the metal into a mixture composed of materials including powdered bone, bone fragments and animal fat (cf. Bauvais 2007: 401). obstructed the osteological determination. The numerous burn marks observed may correspond to phases in the preparation and consumption of meat (boiled or braised), essentially from the domestic triad. The remains of dogs, horses and other species (red deer, wild boar, hare and fish) show extremely low representation rates that rarely exceed $1.5 \%$.

Lastly, it is interesting to note that the remains of dogs are characterised by an over-representation of skull and metapode elements, similar to the faunal spectra observed in the sector of the southern ditch at Villeneuve-Saint-Germain (in much smaller proportions). This may be an indication of the use of dog skins in the forge, the purpose of which is still unexplained.

The spatial organization of Villeneuve-Saint-Germain has always been the subject of debate. The monumentality of the installations has impressed many researchers, and despite a large number of studies the purpose of the ditches, recently determined to have been covered, remains unexplained. The objective here is not to attempt to explain how the site functioned, but rather to question the nature of the activities that took place here, and to consider the reason why such an installation was created.

Once again, a dichotomy between the faunal assemblages from the living zone and from the southern ditch (Fig. 6) is evident: 
A

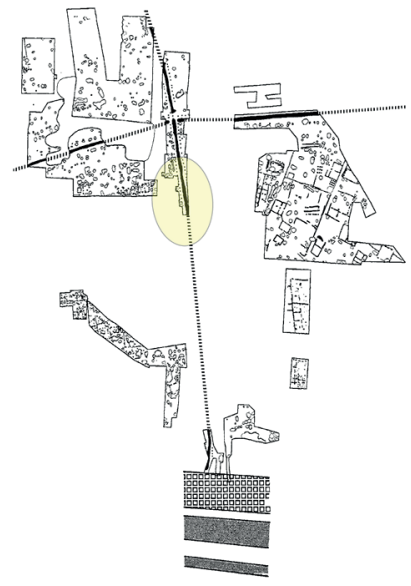

A73X Feature numbers

$\square$ Features

Posts

Neolithic features

J. Debord excavations

Fauna studied by P.-E. Paris

Modern drainage trench

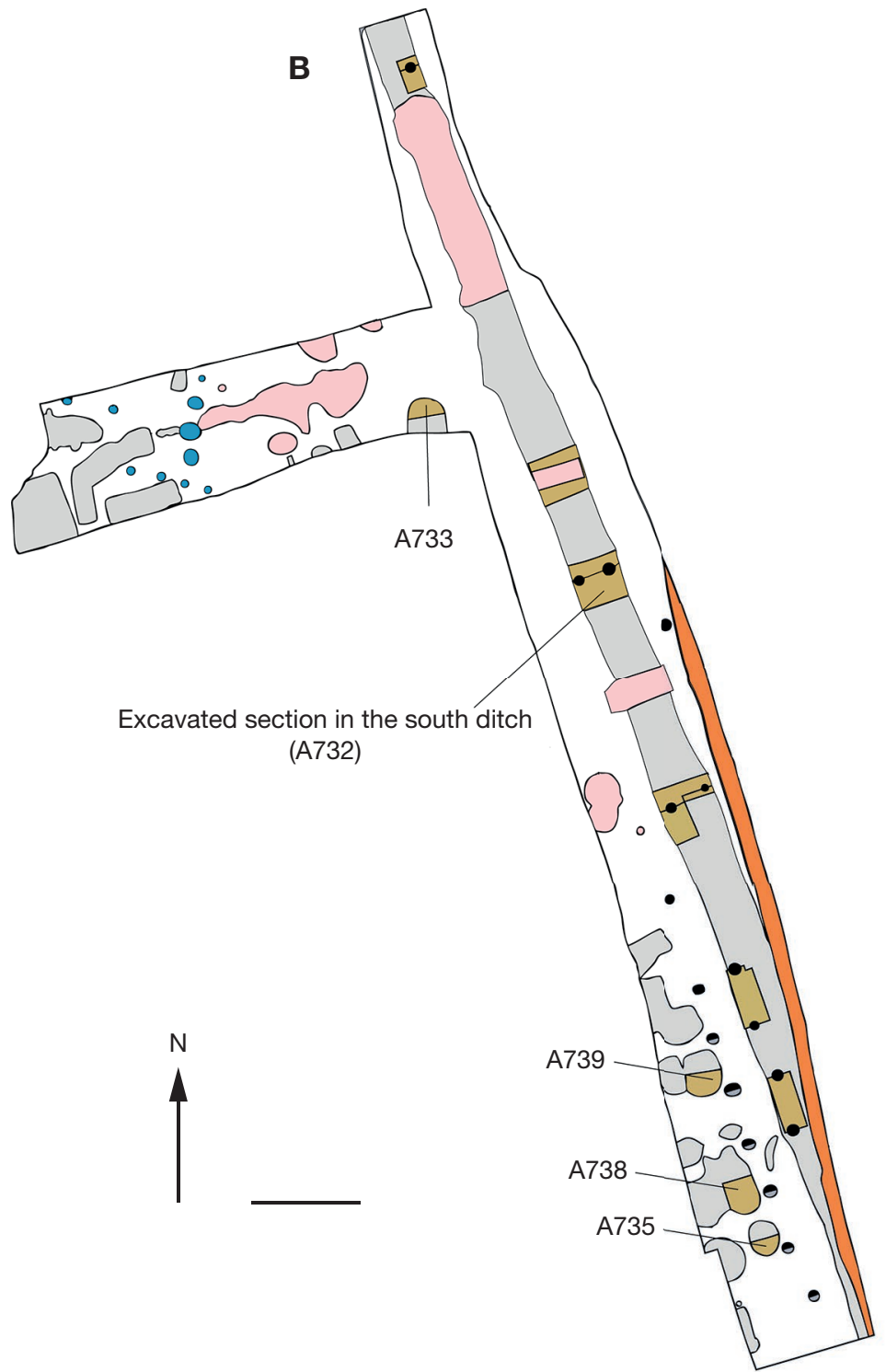

FIG. 7. - Plan of the southern ditch sector on the site of Villeneuve-Saint-Germain: A, general plan of the site of Villeneuve-Saint-Germain (from Pion 1996); B, southern ditch sector on the site of Villeneuve-Saint-Germain (from Ruby \& Auxiette 2010). Scale bar: $10 \mathrm{~m}$.

the features in the living zone and from around the ditch have mainly produced remains of pig or caprinae, while the fill of the southern ditch (A732) indicates an exploitation primarily involving bovinae. In addition, it can be observed that features F01 and F12 also possess a faunal spectrum with a significant proportion of cattle remains. These are the two features mentioned above, the first of which contains the only bovine skull in the zone and the second of which contains the remains of a number of "retired" cattle. It is not surprising to see that this particularity stands out in the triangle plot. On the contrary, this reinforces the idea that only one or two house units dealt with the in situ slaughter of "retired" bovids. In a more general manner, we observe in the living zone waste indicators of classic consumption, with an over-representation of rib and vertebral elements but also of the lower members. Meat seems to have been consumed boiled, as indications of exposure to fire are rare across the whole of the zone. However, we cannot exclude the consumption of dried meat without prior cooking. During previous studies, F. Gransar and O. Weller have observed significant indicators of exposure to salt in several dolia discovered within house units (Wellen \& Robert 1995: 93). The over-representation of lower members (shoulders) in this sector may support this hypothesis, which also deserves closer examination by systematic cross-referencing of the pottery and zooarchaeological data.

The homogeneous fill of the southern ditch (feature A732), however, presents different indicators as to the processing of meat (Fig. 7). The fill mainly contains remains of cattle slaughtered methodically between their second and third years. The anatomical sections are generally quite unfragmented. They were undoubtedly the product of an initial butchering phase in which the carcass was cut into large quarters (a butchering method that is still widely used today). The second butchery phase - which this time took place within the living zone and along the periphery of the ditches (Fig. 8) - corresponds 
to the consumption or preparation of the meat. The ditches described as "peripheral" which adjoin these ditches do not seem to have been directly included in the urban fabric of the living zones and their function remains unclear: some possess very similar fills to those observed in the main ditches, which others tend to produce a faunal consumption profile similar to those observed in the living zones. The butchery chaînes opératoires demonstrate once again the high degree of standardization achieved by these societies, who possessed remarkable knowledge in terms of butchery well before the Roman acculturation. It is therefore not surprising to find the same butchery cuts in different geographical and social contexts, as once achieved, the skills involved in butchering an animal carcass can develop only in terms of intensity. For this reason, the site of Villeneuve-Saint-Germain provides an exceptional case study. G. Auxiette describes the work of the artisans at Villeneuve-Saint-Germain as "specialization in the butchery of large animals, on a large scale" (Auxiette 1996: 84). The examination of the southern ditch (A732) proposed here fully confirms this hypothesis. For a surface area investigated of around 1369 square meters (P. Ruby pers. comm.) - a relatively small area compared to the four ditches that divide the space - a minimum of 21 animals were subject to systematic and standardised butchery. This over-production of meat is comparable to the carpological evidence described by V. Matterne, indicating that "agricultural intensification [...] is a strategy" (Matterne 2000: 146). The generalisation of surplus production seems to have been a response to the considerable pressures experienced during the $3^{\text {rd }}$ century B.C. by the Gallic peoples. This new economic strategy was, in part made possible by the rapid and significant grouping of the population within these fortified settlements. The exploitation of meat - an important food commodity in the dietary regime of these peoples - thus also underwent a major increase, which necessitated not only ever greater specialisation among the craftsmen carrying out the butchery, but also a large production space linked to these huge ditched features.

These ditches also indicate other craft activities. J. Debord, who carried out a great deal of work on the question, has revealed areas of differential concentration of artefacts - metallic objects, bone objects, coins etc. - depending on the sections of the ditches studied (Debord 1993: 89-95).

The southern ditch is clearly an area in which the production of furs was particularly important. Here we have the greatest concentration of dog remains ever observed, characterised once again by very numerous elements of skulls and metapodes (Yvinec 1987: 89). This high concentration, in such a specific sector, enables us to envisage within the settlement a specialisation in the production of animal skins, distributed at least partially to houses where they were "used in place of cushions" (Diodorus Siculus Book V: 362-363).

Some of the fortified settlements from the late Iron Age are therefore distinguished by new features, principally devoted to a variety of craft or butchery activities. While iron production seems to have been predominant at Condé-sur-Suippe, the sector of the southern ditch at Villeneuve-Saint-Germain is characterised by the presence of a major area of butchery activity. S. Foucras has observed an analagous phenomenon. In a detailed study of the Arverni, he has revealed a further area of intense butchery activity at the oppidum of Corent (Puy-de-Dôme). The analogy with the Roman macella ${ }^{3}$ is, as indicated by S. Foucras in his doctoral thesis, "still far from being clear" (Foucras 2010: 142). Nonetheless, we can already question the role that Roman influence played on the Gallic peoples. As regards dietary regimes, we observe a considerable increase in the size of the animals, essentially beef and pork, the status of which developed rapidly throughout the territory once the Roman conquest had been accomplished (Ferdière et al. 2006: 121). We also observe a gradual halt in the consumption of horses, linked to a greater consumption of poultry (Ferdière et al. 2006: 125-128). From the point of view of the urbanization of archaeological sites, the cases of Villeneuve-Saint-Germain and Corent are probably two illustrations of separate responses to a similar social problem which an external factor - Roman acculturation - influenced to a more or less significant degree. The population of the oppidum of Corent - developing in a relatively different social and economic context to that of northern Gaul - thus developed installations similar to the Roman macella, while the site of Villeneuve-Saint-Germain is distinguished by unusual ditched features of very large size but nevertheless possessing the same functional characteristics, i.e. spaces dedicated in part to intense butchery activity intended for the commercialization of some of the animal resources produced in situ.

\section{CONCLUSIONS}

Over a period of two centuries, the Celtic world seems to have taken an important step forward in the development of its economic ideas, partly drawing inspiration from the Mediterranean model (as defined by P. Brun 1994: 59). The impact on meat consumption is of consequence for several reasons: while we observe only minor modifications in diet, this social and political upheaval is indicated more clearly by large scale meat production, requiring on the one hand increased knowledge from the craftsmen responsible for butchery activities and on the other a more general management of the chaîne opératoire - from the management of the herd to the commercialisation of animal resources - which also takes on a new dimension, undoubtedly more intensive than those observed in lower status villages or farms. The case of Acy-Romance on the Rème territory is particularly interesting in this respect (Méniel 2011). The gradual impoverishment of meat resources during the emergence of larger urban entities might be a characteristic trend here, but this would indeed require another study.

The preliminary zooarchaeological examination of the sites of Condé-sur-Suippe and Villeneuve-Saint-Germain, com-

3. A macellum is a public market of the Roman period in the form of an enclosed space with a single entrance. It contained a number of pitches, with stone stalls on which the merchandise, including meat, was exhibited. 


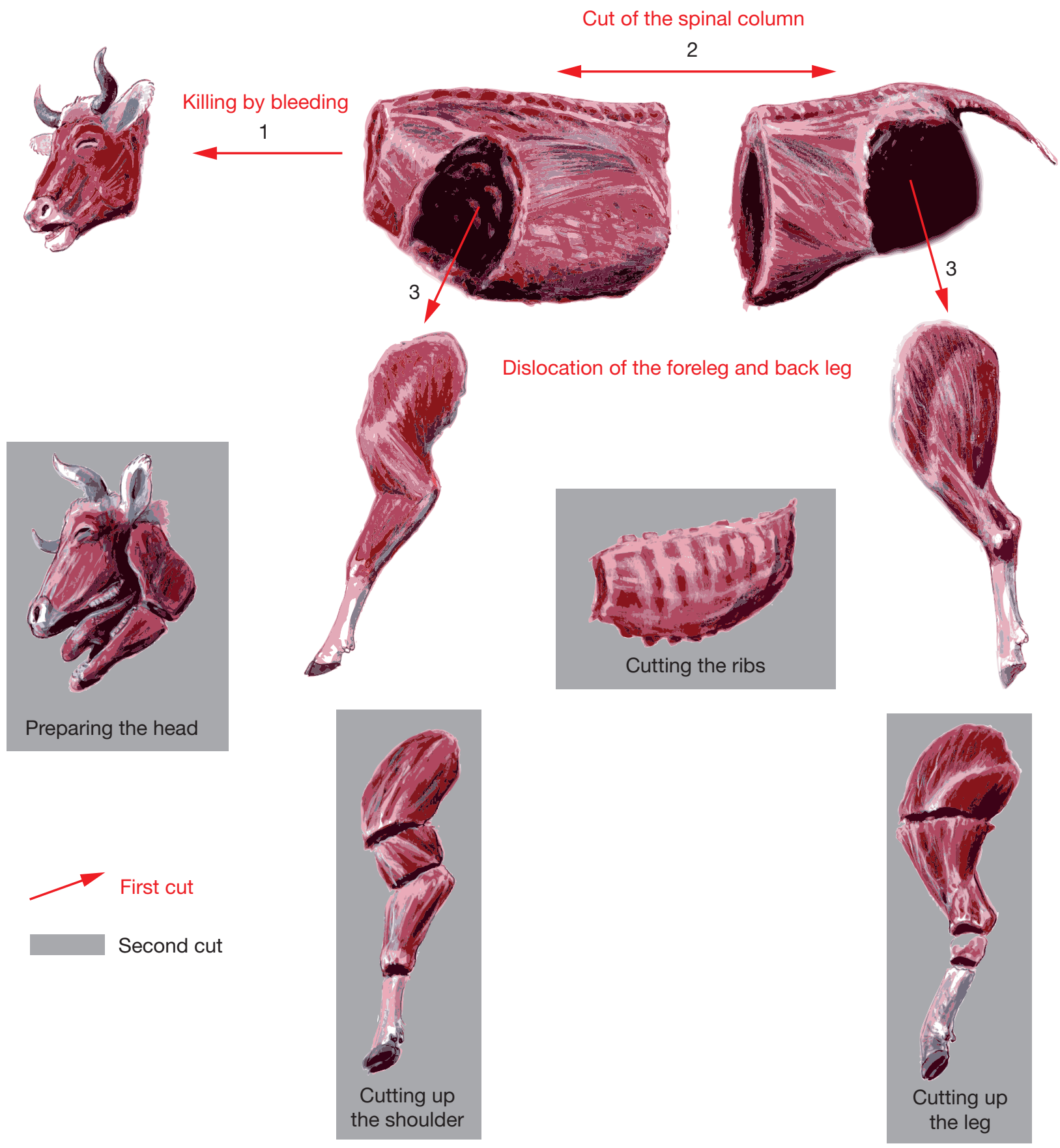

FIG. 8. - Simplified chart of butchery cuts from bovinae according to observations carried out on the site of Villeneuve-Saint-Germain.

bined with a historical vision of changes occurring during this period, enables an interesting reading of the modification in dietary strategy adopted in the Celtic world.

One can only underline the remarkable adaptability of the techniques and knowledge of these populations, who were able to maximise the standardization of butchery to meet increasing economic needs. Not only the management and preparation of meat, but also its consumption had developed since La Tène A: the diversity of animal resources narrowed in favour of standardisation, with the consumption of cows, boar and sheep at mature weight; the consumption and probably the breeding of some herds (in particular bovines at Villeneuve-Saint-Germain) seems to have resulted from the practice already mentioned above of "sharing" pieces of meat; lastly, producing a surplus of meat for commercial purposes seems to have become, at least for the Suessione people, a major challenge which they employed considerable means to achieve.

These considerations, already stated and confirmed relating to the strategic upheavals in the management of animal 
resources observed in La Tène $\mathrm{D}$, open the way for further questions, the socio-political implications of which are essential for a better understanding of protohistoric societies: for whom was the surplus meat produced; what was the impact of the appearance of these large distribution centres on the neighbouring farms and villages, and what was the place of meat products in the intra and inter-territorial trade networks? While we can state today that over-production of meat was at the heart of the new economic regime - for the Suessione people at least - and that strong indications of storage of large pieces of meat can be observed, particularly at VilleneuveSaint-Germain, we must also note that the question of the distribution and circulation of the meat, within one or more territories, has not yet been clarified.

We are not yet in a position to do more than glimpse the future challenges of research if these initial considerations were extended to all oppida. The great La Tène settlements of Belgium, Germany and Bohemia, such as Manching, Titelberg, Radovesice or Zavist could be subject to studies of this type, in order to reveal the presence or absence of the social system that we are beginning to perceive in the Aisne valley.

\section{Acknowledgements}

I would like to thank Pascal Ruby and Ginette Auxiette for their full support during my research on the site of VilleneuveSaint-Germain and also Patrick Pion for guiding my research during the faunal study of Condé-sur-Suippe. I'm also grateful to Patrice Brun for his perceptive comments on this study and, last but not least, my special thanks go to Laurence Manolakakis for encouraging me to publish this paper.

\section{REFERENCES}

Auxiette G. 1994. - Mille ans d'occupation humaine. Mille ans d'élevage. L'exploitation des animaux du Bronze Final à l'Augustéen dans la vallée de l'Aisne. Thèse de doctorat, Université Paris 1 Panthéon-Sorbonne, Paris, France, 3 volumes.

AuXIETTE G. 1996. — La faune de l'oppidum de Villeneuve-SaintGermain (Aisne) : quartiers résidentiels, quartiers artisanaux. Revue archéologique de Picardie 1 (1): 27-98.

AuXIETTE G. 1997. - La faune des établissements ruraux du Bronze final au Hallstatt final/La Tène ancienne dans la vallée de l'Aisne. Revue archéologique de Picardie 3 (1): 29-71.

BAUDRY A. 2012. - Ressources animales et alimentation carnée à l'áge du Fer. Le cas du nord-ouest de la France (Bretagne et BasseNormandie). Thèse de doctorat, Université de Rennes 1, Rennes, France, 385 p.

BAUVAIS S. 2000. - Analyse de la chaîne opératoire de sidérurgie sur l'oppidum de Condé-sur-Suippe (Aisne). DEA, Université Paris 1 Panthéon-Sorbonne, Paris, France, 139 p.

BAUVAIS S. 2007. - Évolution de l'organisation des activités de forge dans le nord du bassin parisien au second âge du Fer : études pluridisciplinaires de la chaîne opératoire en métallurgie du fer. Thèse de doctorat, Université de technologie de Belfort-Montbéliard; Université de Franche-Comté, Besançon, France, 3 volumes.

BRUN P. 1994. - From the Hallstatt to La Tène period in the perspective of the mediterranean world economy, in KRISTIANSEN K. \& JENSEN J. (eds), Europe at the first Millenium B.C. Sheffield Archaeological Monographs 6: 57-65.
Brun P., Chartier M. \& Pion P. 2000. - Le processus d'urbanisation de la vallée de l'Aisne, in Actes Du Colloque du Centre archéologique européen du Mont Beuvray, Glux-en-Glenne, 8-11 juin 1998. Bibracte 4: 83-96.

BRUN P. \& RUBY P. 2008. - L'âge du Fer en France : premières villes, premiers états celtiques. Ed. la Découverte, Paris, $178 \mathrm{p}$.

CAMBou D. 2009. - L'élevage et l'alimentation carnée en Bourgogne de La Tène finale au bas empire (130 Av.-325 Ap. J.-C.). Une analyse des ossements issus des dépotoirs domestiques. Thèse de doctorat, Université de Bourgogne, Dijon, France, 250 p.

DeBORD J. 1974. - Villeneuve-Saint-Germain (Aisne). Rapport de fouille, $50 \mathrm{p}$

DEBORD J. 1993. - Les artisans gaulois de Villeneuve-Saint-Germain (Aisne). Structures, production, occupation du sol. Revue Archéologique de Picardie 3 (1): 71-110.

Debord J., Buchenschutz O. \& Lambot B. 1988. — Les fossés couverts du site gaulois tardif de Villeneuve-Saint-Germain (Aisne). Dossier de Protohistoire 2: 121-135.

Diodorus Siculus - Bibliothèque Historique. Livre V. in Y. Germain \& E. DE BussaC (eds), E. Cougny (trad.), Moeurs et coutumes des Gaulois d'après le témoignage des historiens grecs, Éditions Paleo, Paris: 2010.

Ferdière A., Malrain F., Matterne V., Méniel P. \& Nissen Jaubert A. 2006. - Histoire de l'agriculture en Gaule : 500 av. J.-C.-1000 apr. J.-C., Errance, Paris, 261 p.

FILET C. 2012. - Réflexion sur l'organisation architecturale des agglomérations celtiques en Europe tempérée humide (150-25 av. J.-C.). Master 1, Université Paris 1 Panthéon-Sobonne, Paris, France, 204 p.

FOUCRAS S. 2010. - Animaux domestiques et faune sauvage en territoire arverne (Ve s. av. J.-C.- Ier s. ap. J.-C.). Thèse de doctorat, Université de Bourgogne, Dijon, France, 284 p.

Germinet D. 2009. - Homme et animal dans les fermes du Poitou à la transition âge du Fer période gallo-romaine. Thèse de doctorat, Université de Tours François - Rabelais, Tours, France, 886 p.

GRANSAR F. 2000. — Le stockage alimentaire sur les établissements ruraux de l'âge du Fer en France septentrionale : complémentarité des structures et tendances évolutives in Les installations agricoles de l'âge du Fer en France septentrionale. Études d'Histoire et d'Archéologie, Editions Rue d'Ulm, Presses de l'École Normale Supérieure, Paris: (6) 277-297.

Malrain F., Matterne V. \& Méniel P. 2002. — Les paysans gaulois. Collection des Hespérides, Errance, Paris, 236 p.

MatTERNE V. 2000. - Évolution des productions agricoles durant l'âge du Fer dans le Nord de la France, in Les installations agricoles de l'âge du Fer en France septentrionale. Études d'Histoire et d'Archéologie, Éditions Rue d'Ulm, Presses de l'École Normale Supérieure, Paris: (6) 129-146.

MÉNIEL P. 1984. - Contribution à l'histoire de l'élevage en Picardie du Néolithique à la fin de l'âge du Fer. Revue Archéologique de Picardie Vol. spécial: 56 p.

MéNIEL P. 1998. — Le site protohistorique d'Acy-Romance (Ardennes) - III. Les animaux et l'histoire d'un village gaulois. Fouille 1989-1997. Mémoire de La Société archéologique champenoise Vol. Hors série: $175 \mathrm{p}$.

MÉNIEL P. 2011. - Histoire de l'alimentation carnée dans le village gaulois d'Acy-Romance (IIe-Ier BC, Ardennes, France), in De la cocina a la mesa. Saguntum Extra 9: 57-68.

PARIS P.-E. 2015. - Au fil de l'os. Économie et société des populations protohistoriques du nord de la France à travers la documentation archéozoologique : les cas de Condé-sur-Suippe et Villeneuve-SaintGermain. Thèse de doctorat, Université Paris 1 Panthéon-Sorbonne, Paris, France, 748 p.

PION P. 1990. - Oppidum du vieux-Reims : Condé-sur-SuippeVariscourt (Aisne) : sauvetage programmé 1987 (extension de la sucrerie). Rapport de synthèse, $129 \mathrm{p}$.

PION P. 1998. — Les habitats laténiens tardifs de la vallée de l'Aisne: contribution à la périodisation de la fin du second Âge du Fer en Gaule nord-orientale (LT.C2 - période augustéenne précoce, IIe-Ier 
siècles av. J.-C.). Thèse de doctorat, Université Paris 1 PanthéonSorbonne, Paris, France, 3 volumes.

Pion P., Pommeruy P., Auxiette G., Hénon B. \& Gransar F. 1997. — L'oppidum de Condé-sur-Suippe / Variscourt (Aisne) (fin IIe-début Ier siècle av. J.-C.) : approche préliminaire de l'organisation fonctionnelle d'un quartier artisanal, in Actes $d u$ colloque: l'Analyse spatiale des sites du Néolithique à l'àge du Fer, 119 ime Congrès National des Sociétés Historiques et Scientifiques, Amiens, 26-30 octobre 1994, Ed. du Comité des Travaux historiques et scientifiques (CTHS), Paris: 275-309.

RENaUd D. 2012. - Alimentation carnée et gestion des populations animales sur le territoire de la cité de Nîmes (Hérault et Gard, IIème s. av.-IIème s. ap. J.-C.). Thèse de doctorat, Université Paul Valéry, Montpellier III, Montpellier, France, 699 p.

Ruby P. \& Auxiette G. 2010. - 1977-2007 Trente ans de recherches sur les "fossés en croix» de l'oppidum de Villeneuve-
Saint-Germain. Revue archéologique de Picardie 3-4: 39-94.

SALIN M. 2010. - Animaux et territoire l'apport des données archéozoologiques à l'étude de la cité des Bituriges Cubi (Ier s. av. J.-C. - Ves. ap. J.-C.). Ed. de Bourges plus, Service d'archéologie préventive ; Fédération pour l'édition de la Revue archéologique du Centre de la France, Tours, 313 p.

Sidi MAAMAR H. 2001. - Approche anthropozoologique d'une communauté villageoise alpine du premier et second âge du fer. Analyse de la faune du site de Brig-GlisWaldmatte (Valais, Suisse), Thèse de doctorat, Université Paris 1 Panthéon-Sorbonne, Paris, France, 630 p.

Weller O. \& RoberT B. 1995. — Le commerce du sel au La Tène final : une problématique enfin relancée. Revue Archéologique de Picardie 1 (1): 87-96.

YVINEC J.-H. 1987. - Découpe, pelleterie et consommation des chiens gaulois à Villeneuve-Saint-Germain. Anthropozoologica Numéro spécial 1: 83-90.

Submitted on 16 June 2014; accepted on 10 October 2014; published on 26 June 2015. 


\section{APPENDIX}

Corpus of the two oppida studied. The structures presenting a number of fragments smaller than 10 have been discounted. Abbreviations: CSS, Condé-surSuippe; N. F. def., number of fragments defined; N. F. undef., number of fragments undefined; VSG, Villeneuve-Saint-Germain.

\begin{tabular}{|c|c|c|c|c|c|c|c|c|c|c|c|}
\hline Localisation & $\begin{array}{c}\text { Cattle } \\
\text { Bos } \\
\text { taurus }\end{array}$ & $\begin{array}{l}\text { Sheep/Goat } \\
\text { Ovis aries/ } \\
\text { Capra hircus }\end{array}$ & $\begin{array}{c}\text { Dog } \\
\text { Canis } \\
\text { familiaris }\end{array}$ & $\begin{array}{c}\text { Pig } \\
\text { Sus } \\
\text { domesticus }\end{array}$ & $\begin{array}{c}\text { Horse } \\
\text { Equus } \\
\text { caballus }\end{array}$ & Avifauna & N.F. def. & N.F. undef. & Total N. F. & $\%$ def. & $\%$ undef. \\
\hline $\begin{array}{l}248 \\
249 \\
252 \\
257 \\
280 \\
282 \\
285 \\
332 \\
334 \\
336\end{array}$ & $\begin{array}{r}8 \\
3 \\
12 \\
34 \\
4 \\
1 \\
0 \\
0 \\
3 \\
5\end{array}$ & $\begin{array}{r}8 \\
0 \\
6 \\
42 \\
7 \\
3 \\
1 \\
0 \\
11 \\
0\end{array}$ & $\begin{array}{l}5 \\
0 \\
3 \\
5 \\
0 \\
1 \\
0 \\
0 \\
0 \\
0\end{array}$ & $\begin{array}{r}24 \\
9 \\
49 \\
111 \\
39 \\
6 \\
8 \\
10 \\
52 \\
14\end{array}$ & $\begin{array}{l}0 \\
0 \\
0 \\
4 \\
0 \\
0 \\
0 \\
0 \\
0 \\
0\end{array}$ & $\begin{array}{l}0 \\
0 \\
0 \\
0 \\
0 \\
0 \\
0 \\
0 \\
0 \\
0\end{array}$ & $\begin{array}{r}45 \\
12 \\
70 \\
196 \\
50 \\
11 \\
9 \\
10 \\
66 \\
19\end{array}$ & $\begin{array}{r}16 \\
9 \\
11 \\
153 \\
52 \\
10 \\
8 \\
6 \\
24 \\
13\end{array}$ & $\begin{array}{r}61 \\
21 \\
81 \\
349 \\
102 \\
21 \\
17 \\
16 \\
90 \\
32\end{array}$ & $\begin{array}{l}73.8 \\
57.1 \\
86.4 \\
56.2 \\
49.0 \\
52.4 \\
52.9 \\
62.5 \\
73.3 \\
59.4\end{array}$ & $\begin{array}{l}26.2 \\
42.9 \\
13.6 \\
43.8 \\
51.0 \\
47.6 \\
47.1 \\
37.5 \\
26.7 \\
40.6\end{array}$ \\
\hline Sub-total CSS & 70 & 78 & 14 & 322 & 4 & 0 & 488 & 302 & 790 & 61.8 & 38.2 \\
\hline $\begin{array}{l}\text { F01 } \\
\text { F02 } \\
\text { F03 } \\
\text { F04 } \\
\text { F05 } \\
\text { F06 } \\
\text { F07 } \\
\text { F08 } \\
\text { F09 } \\
\text { F11 } \\
\text { F12 } \\
\text { A732 } \\
\text { A733 } \\
\text { A735 } \\
\text { A738 } \\
\text { A739 }\end{array}$ & $\begin{array}{r}19 \\
9 \\
9 \\
4 \\
2 \\
7 \\
12 \\
3 \\
1 \\
5 \\
11 \\
555 \\
41 \\
33 \\
126 \\
22 \\
\end{array}$ & $\begin{array}{r}4 \\
5 \\
7 \\
25 \\
27 \\
35 \\
5 \\
9 \\
2 \\
8 \\
4 \\
106 \\
11 \\
10 \\
30 \\
12\end{array}$ & $\begin{array}{r}2 \\
0 \\
4 \\
0 \\
0 \\
3 \\
2 \\
0 \\
0 \\
0 \\
0 \\
47 \\
14 \\
3 \\
1 \\
4 \\
\end{array}$ & $\begin{array}{r}14 \\
54 \\
22 \\
51 \\
30 \\
25 \\
28 \\
22 \\
11 \\
23 \\
10 \\
377 \\
120 \\
87 \\
363 \\
96\end{array}$ & $\begin{array}{l}0 \\
0 \\
0 \\
0 \\
0 \\
0 \\
0 \\
0 \\
0 \\
0 \\
0 \\
6 \\
0 \\
0 \\
0 \\
0\end{array}$ & $\begin{array}{l}0 \\
0 \\
0 \\
0 \\
1 \\
0 \\
0 \\
0 \\
0 \\
0 \\
0 \\
9 \\
2 \\
0 \\
8 \\
2\end{array}$ & $\begin{array}{r}39 \\
68 \\
42 \\
80 \\
60 \\
70 \\
47 \\
34 \\
14 \\
36 \\
25 \\
1100 \\
188 \\
133 \\
528 \\
136 \\
\end{array}$ & $\begin{array}{r}11 \\
59 \\
18 \\
34 \\
23 \\
19 \\
25 \\
7 \\
4 \\
8 \\
3 \\
224 \\
12 \\
12 \\
44 \\
8 \\
\end{array}$ & $\begin{array}{r}50 \\
127 \\
60 \\
114 \\
83 \\
89 \\
72 \\
41 \\
18 \\
44 \\
28 \\
1324 \\
200 \\
145 \\
572 \\
144 \\
\end{array}$ & $\begin{array}{l}78.0 \\
53.5 \\
70.0 \\
70.2 \\
72.3 \\
78.7 \\
65.3 \\
82.9 \\
77.8 \\
81.8 \\
89.3 \\
83.1 \\
94.0 \\
91.7 \\
92.3 \\
94.4\end{array}$ & $\begin{array}{r}22.0 \\
46.5 \\
30.0 \\
29.8 \\
27.7 \\
21.3 \\
34.7 \\
17.1 \\
22.2 \\
18.2 \\
10.7 \\
16.9 \\
6.0 \\
8.3 \\
7.7 \\
5.6\end{array}$ \\
\hline Sub-total VSG & 859 & 300 & 80 & 1333 & 6 & 22 & 2600 & 511 & 3111 & 83.6 & 16.4 \\
\hline TOTAL & 929 & 378 & 94 & 1655 & 10 & 22 & 3088 & 813 & 3901 & 79.2 & 20.8 \\
\hline
\end{tabular}

